\title{
Talent Management in Knowledge-Intensive Organizations
}

\author{
Melissa Schroevers and Paul Hendriks \\ Radboud University Nijmegen, Nijmegen School of Management \\ The Netherlands
}

\section{Introduction}

In many organizations knowledge becomes increasingly important for sustaining competitive advantage. Knowledge-intensive firms (KIFs; Alvesson, 2004) gain competitive advantage by continuous adaptation to their environment. This constant adaptation to the competitive environment is realized by the unremitting generation and use of new knowledge (Harrison \& Kessels, 2004, p. 3). Thus, for KIFs the strategic capacity to compete flows from knowledge; this knowledge is mainly derived from people (Kessels, 2004). Therefore it is assumed that managing their workforce's knowledge has become ever more critical to organizations. The relevance of HRM to knowledge management debates has long been noticed (e.g. Haesli \& Boxall, 2005; Scarbrough, 2003; Storey \& Quintas, 2002). Knowledge presumes knowing subjects, and therefore management focusing on knowledge and learning needs to pay attention to these subjects. Because of the emphasis on the knowledge people in knowledge-intensive firms possess and may create, organizations constantly need to find ways to make better use of this knowledge. Here, improved knowledge usage does not just concern better exploitation of existing knowledge sources but also leveraging the knowledge creation capability hidden in available knowledge. Even the most intelligent knowledge-based systems remain void of knowledge without intelligent users of these systems. As Kaulingfreks (2002) argues, knowledge management in an ICToriented approach easily runs the risk of producing erudite folly because of its preoccupation with information. What gets lost in even the most user-friendly and fully updated storage of best practices, Kaulingfreks argues, is the contextual, individual, nontransferrable, purposeless activity that knowledge is. Introductions into KM nowadays are considered incomplete if they do not pay sufficient attention to HRM and HRM handbooks typically include a chapter or section on knowledge and learning (e.g. Harrison \& Kessels, 2004; Redman \& Wilkinson, 2006; Adams, 2006).

A possibly interesting yet mostly unexplored domain of managing knowledge via HRM is by means of talent management. Since the late 1990s the interest in the topic of talent management has grown considerably. In 1997 a group of McKinsey consultants formulated the importance of talent for the performance of organizations by coining the 'War for Talent'. Since then the topic of talent management has received a remarkable degree of practitioner and academic interest (Gollings \& Mellahi, 2009, p. 2). Changes in the environments of organizations such as globalization, growing operational complexity, an aging workforce, scarcity of talent, and greater international workforce mobility made the 
competition for talented knowledge workers a business case. 'Talent is the oil of the future and is the key to strategic success. Talent means all people in an organisation that contribute to its goals and competitive advantage' (Van der Sluis, 2009). Nowadays, most companies are experiencing a shortage of top talent as well as tough competition for talent (Heinen \& O'Neill, 2004, p. 67). In 1998 Fishman already predicted a growing interest in the field of talent management in the near future: 'The most important corporate resource over the next 20 years will be talent: smart, sophisticated business people who are technologically literate, globally astute, and operationally agile. And as the demand for talent goes up, the supply of it will be going down' (Fishman, 1998, p. 1).

Connections between talent and its management on the one hand and subjects of knowledge and learning in organizations on the other seem logical and possibly fruitful. Yet subjects of knowledge management hardly receive any systematic attention in the talent management literature. Also the knowledge management and organizational learning literatures do not seem to have embraced notions of talent management. This paper aims to explore the potential of linking the fields of talent management and knowledge management, The method taken in this research is that of a literature review of the emerging stream of talent management studies via a knowledge and learning perspective that is derived from a literature review of the knowledge management literature. To meet these objectives, the chapter addresses three questions:

1. What is the definition of talent management; what do different literature views say about the definitions on talent management and their scopes?

2. Why should we aim at linking talent management to debates on knowledge management and organizational learning? What debates regarding the latter two fields can be supported by adding insights from the talent management domain?

3. How would talent management when linked to $\mathrm{KM} / \mathrm{OL}$ help envision practical implementation of management programmes around knowledge and learning? This question refers to the objectives as well as the means of talent management in light of knowledge-related challenges and problems. For example, a relevant debate concerns which HR practices can be applied to achieve the objectives of talent management to support knowledge and learning processes. Which approaches does talent management offer that may help organizations meet their knowledge-related objectives?

\section{Towards a definition of talent management}

It is no easy task to find a unanimously accepted definition of talent management. A key limitation in the field of talent management is its lack of a consistent definition (Collings \& Mellahi, 2009, p. 1; Lewis \& Heckman, 2006, p. 139; Cappelli, 2008, p. 74). 'There isn't a single consistent or concise definition of talent management' (Ashton \& Morton, 2005, p. 30). Lewis \& Heckman (2006, p. 139) speak of a 'disturbing lack of clarity regarding the definition, scope and overall goals of talent management'. As Lewis \& Heckman (2006, p. 143) mention: 'Talent management, as defined currently, is not well grounded in research, not distinct from traditional HR practices or disciplines, and is supported mainly by anecdote'. Also, the terms 'talent management', 'talent strategy', 'succession management' and 'human resource planning' are often used interchangeably (Lewis \& Heckman, 2006, p. 140). Thus, despite a growing popularity in the field of talent management and despite hopeful debates between authors, the concept of talent management remains unclear (Collings \& Mellahi, 2009, p. 3). 
A useful starting point for finding a navigation path through the definitional maze that surrounds the talent management concept is provided by Lewis \& Heckman (2006) who identify three distinct streams of thought regarding talent management. First, some studies merely substitute the label of human resource management with talent management by focusing on human resource practices, functions, activities such as recruiting, selection, development and career succession management (Lewis \& Heckman, 2006, p. 140). A second perspective on talent management primarily highlights the concept of 'talent pools' by focusing on 'projecting employee/staffing needs and managing the progression of employee through positions' (Lewis \& Heckman, 2006, p. 140). These approaches typically build on earlier research in the manpower planning/human resource planning or succession planning literature. A third perspective on talent management emphasizes the management of talented people; this perspective involves is a clear focus on talent generically (Collings \& Mellahi, 2009; Lewis \& Heckman, 2006, p. 141). With this approach, all roles within the organization should be filled with employees who are considered 'A performers' or 'top grading' (Smart, 1999).

Two assertions can be made. First, of these three streams only the third type of definition seems to offer a serious attempt to provide a foothold for asking who is to be considered a 'talent' and what is the 'talent' that this person has or should have. The first two classes (talents as substitute for HR or talent as element of a pool to be developed) seem to use the concept of talent just for labelling reasons - and perhaps even for rhetoric or advertisement reasons. They would need further elaboration of the concept of talent. And second, the three types of definition do not represent approaches that are conceptually at odds with one another, but provide perspectives that may be combined (e.g. one can easily combine stream 3 typified by its focus on A-performers with the attention for talent pools in stream 2). To explore these linkages we can inspect some of the definitions of talent management given in the literature.

Cappelli (2008, p. 74-76) defines talent management as 'a matter of anticipating the need for human capital and then setting out a plan to meet it'. He mentions the need for a fundamentally new approach to talent management that takes into account the great uncertainty businesses face today. By borrowing lessons from operations and supply chain research, firms can forge a new model to make talent management better suited to today's realities (Cappelli, 2008, p. 76). Cappelli's definition fits with the third perspective on talent management because of the focus on (the management of) talented human capital.

Another example that fits the third stream is provided by Frank and Taylor (2008). These authors acknowledge the evolutionary changes that will permanently affect how we approach talent management. 'Workplaces everywhere are facing an increasingly complex and ever-changing landscape in their efforts to acquire, retain, motivate and develop the talent needed to keep their organizations operating efficiently and competitively' (Frank and Taylor, 2008, p. 34). This definition also acknowledges the need for talent and therefore their definition of talent management also fits in the third stream of thought regarding the concept of talent management as identified by Lewis \& Heckman (2006). However, because of their focus on human resource practices such as recruitment and development of employees and because of the emphasis on strategic goals ('operate efficiently and competitively'), this definition adds elements of the first perspective on talent management: 'talent management as a substitute for strategic human resource practices'.

A third example, also within the third stream, can be found in Fishman (1998). According to this author, talent management refers to the skills of attracting highly skilled workers, of 
integrating new workers, and developing and retaining current workers to meet current and future business objectives. This process of attracting and retaining profitable employees in order to strive for competitive and strategic advantage has come to be known as 'the war for talent'. Because it acknowledges the need for talent in order to achieve business objectives, the definition of Fishman (1998) is consistent with the third perspective on talent management which emphasizes the management of talented people. But here too this is combined with the first perspective on talent management, given the focus on human resource practices.

Several other authors emphasize the interests and strategic objectives of the organization in implementing talent management practices when defining talent management. For example, Van Aken (1991) defines talent management as 'the way in which managers manage their employees in order to deploy their talents as much as possible for the benefit of the success of the organization'. The success and competitive advantage of the organization is also emphasized in the following definition of Mensink (1991). According to Mensink (1991), 'talent management is the stimulation of people/employees to perform as well as possible to shed light upon the success of the organization'. Also Van der Sluis (2009) recognizes the importance of talent in achieving organizational objectives: 'Talent means all people in an organisation that contribute to its goals and competitive advantage' (Van der Sluis, 2009). Because of the focus on strategic objectives, these definitions too fit the third, general perspective on talent management in which there is a clear focus on the management of talent in general in order to strive for competitive advantages.

Next to the two remarks regarding Lewis and Heckman's (2006) triplet of talent management approaches made above, a third remark has to be that the three streams identified by these authors do not cover the full breadth of the talent management debates. Collings \& Mellahi (2009) add an emerging fourth stream of thought regarding talent management to these three key streams. These authors define strategic talent management as: 'activities and processes that involve the systematic identification of key positions which differentially contribute to the organization's sustainable competitive advantage, the development of a talent pool of high potential and high performing incumbents to fill these roles, and the development of a differentiated human resource architecture to facilitate filling these positions with competent incumbents and to ensure their continued commitment to the organization' (Collings \& Mellahi, 2009, p. 9). They recognize an emphasis on the identification of key positions rather than talented individuals per se (Collings \& Mellahi, 2009, p. 6). This emphasis is not present in any of the other three streams, which justifies assigning definitions of talent management in terms of key positions to a fourth stream.

In summary, it can be concluded that a clear, broadly accepted definition of talent management is lacking in the literature. Because of this, an integrated definition of talent management cannot simply be derived from the extant literature but needs to be constructed. What the assorted definitions show is that a key element involves a focus on the talent of employees in order to enhance the organizational performance. The concept of talent should be read as a combination of (1) people ('A-performers'), (2) the specific skills and competencies of these individuals (the talents of the A-performers) and (3) key positions within the firm to address the linkage between these talented individuals and their organizational role (in the talent management domain, someone is not to be considered a talent because of her individual traits in isolation but always in connection to organizational processes and objectives). Human resource practices and talent pool programmes can then 
be perceived and designed as means to stimulate organizational success via these talents. This allows us to conceive of the conceptual unity that binds the four streams on talent management that have been distinguished. These four streams are: 'talent management as HR practices', 'talent pools', 'the management of talented people' and the 'identification of key positions'. The latter two appear as the home base for coming to grips with the concept of talent as a domain for management, with the first two as extensions to allow the specification of management programmes and approaches.

\section{Why look for linkages between talent management and knowledge management?}

The second question identified in the introduction concerns the reasons for linking talent management to knowledge management and organizational learning. To answer this question, an inspection of the knowledge management field is called for. Two main streams can be discerned in the development of the knowledge management field (e.g. Hislop, 2009; Chiva \& Alegre, 2005; Schultze \& Stabell, 2004). One stream approaches knowledge as a functional resource, and provides a perspective for how that resource can be approached to identify its unique strategic potential (Zack, 1999) as a starting point for drafting management programmes for achieving that potential by knowledge management programmes and tools. Historically, especially the class of ICT tools has attracted much attention but within this functionalist approach to KM also several authors discuss the possibilities of HR programmes. A second stream has emerged, which can now be seen as an integral element of the knowledge management perspective, adopting a critical stance with regard to the functionalist perspective (e.g. Alvesson, 2004; Tsoukas, 2005; Brown \& Duguid, 1998; Cook \& Brown, 1999). This stream challenges the potential of knowledge as a functionalist resource, because thinking of knowledge as a resource would involve a conceptual impoverishment in our understanding of the very nature of knowledge (e.g. the way functionalist KM thinkers treat the fundamental category of tacit knowledge leads Tsoukas, 2003, to ask the question of 'Do we really understanding tacit knowledge?' needless to say that his answer is 'no', not the way it was intended by Michael Polanyi, the intellectual father of the concept). These authors stress the importance of social processes and social context in which knowledge is created, and recreated. When divorced from social context, as happens when only the content side to knowledge is recognized as the basis for 'knowledge' storage in ICT systems or when knowledge domains are specified in HR development programmes, knowledge is considered to be void of meaning. Within that second stream, knowledge management is considered by many authors as a vague and ambiguous field of study. Knowledge management is a term which is difficult to understand because knowledge is something which cannot really be managed.

Several authors, including Alvesson (1993, 2001), Becker (2001), Sewell (2005) and Tsoukas (1996), identify a focus on 'ambiguity' when describing the dominance and understanding of the nature and significance of 'knowledge' in contemporary companies and in particular in knowledge-intensive firms. These authors emphasize the ambiguity of knowledge work and the struggle knowledge-intensive organizations have with it. Not only the concept of knowledge is ambiguous, but also the role of knowledge in a knowledge-intensive company is ambiguous. "Ambiguity, (involving uncertainty, contradictions that cannot be resolved or reconciled, absence on agreement on boundaries, clear principles or solutions), then is seen as a crucial element in work and organization" (Alvesson, 1993, p. 1002). Ambiguity is 
different from uncertainty, because more information does remove the uncertainty, but does not delete ambiguity. Ambiguity refers to the reduction of the ability to make a qualified judgement on a certain situation (Alvesson, 1993; Becker, 2001; Tsoukas, 1996).

Institutionalized myths are a way of claiming to be knowledge-intensive. Beliefs that are taken for granted bridge the gap between claims of rationality and the ambiguity within the organization. Hence, the focus changes from the formal knowledge to the strategies that persuade all stakeholders involved to convince them of the expertise and knowledge that is employed by the organization (Alvesson, 1993). KIFs are typically more concerned with being socially recognized as being an expert than ultimately being one. Consequently, various rhetorical strategies are employed to create a rhetoric that stresses the personal qualities, besides the knowledge base that knowledge workers are claimed upon, that knowledge workers must possess to appear qualified. In this myth perspective, knowledge has other roles such as:

“a) a means for creating community and social identity through offering organizational members a shared language and promoting their self-esteem, b) a resource for persuasion in, for example, PR work and interactions with customers, c) providing the company with a profile (an intended image targeted at the market), d) creating legitimacy and good faith regarding actions and outcomes, and e) obscuring uncertainty and counteraction reflection" (Alvesson, 1993, p. 1011).

The expertise of the knowledge worker is not only expressed by an objective result, but also symbolizes rationality, intelligence, quality etc. Knowledge can hence not be isolated and be seen as a particular that is in itself important and the success of knowledge-intensive work is contingent upon beliefs about knowledge workers offering something specific (Alvesson, 2000). Knowledge does not exist separate from the social processes of interpretation and meaning creation (Alvesson, 2000). Ambiguity involved in meaning creation processes is the foundation for the 'quality' of knowledge.

Alvesson $(1993 ; 2000 ; 2001)$ proposes a new theoretical framework for the concepts of knowledge and knowledge work, involving three kinds of ambiguity: 1) ambiguity of knowledge, 2) ambiguity of the significance of knowledge, and 3) ambiguity of results claimed to be contingent upon knowledge work. The ambiguity of knowledge refers to the claimed core product and the varying definitions on what knowledge is claimed to be in knowledge-intensive firms. Second, knowledge is not necessarily significant in work, because it is connected to flexibility, motivation, social skills, ways of operating, and other elements that are involved in doing knowledge-intensive work. Finally, the work results of knowledge work are very hard to evaluate, while knowledge work is a very intangible and complex 'product'. The work results are often subject to uncertainty, because criteria for evaluating the quality are lacking. They are more based on the perception of the client about the degree to which their problem is solved or the outcomes meet the expectations. "Institutionalized assumptions, expectations, recognitions, reputation, images etcetera are important to how the products of KIFOWs [KIFs] are perceived" (Alvesson, 1993, p. 1007). As a result, KIFs can be defined as being very 'ambiguity-intensive', as Alvesson (1993) calls it.

As Alvesson \& Karreman (2001) argue, the term knowledge management has the threat of falling into pieces when both knowledge and management are taken seriously. The functionalist stream with its focus on knowledge as strategic resource and the deployment of knowledge management tools takes management very seriously, which results in an impoverished understanding of knowledge which is hardly different from information. The 
critical, social-constructivist stream of social-practice approaches to knowledge management and organizational learning aims at building a more fully-fledged conceptual image of knowledge, yet at the expense of sidestepping a systematic analysis of the management side. Building a meaningful combination of the two - knowledge ánd management - appears hard, simply because the realm of management stops when ambiguity enters. Or, as Ten Bos (2002) puts it: "The urge to manage knowledge stems from the need to offer management professionals what we know in a neat and well-structured fashion. I believe, however, that knowledge that has been structured and arranged this way, in a certain sense no longer qualifies as knowledge. To put it differently, whoever manages, gives up every claim of knowledge. [...] Management necessarily involves the exclusion of many contents and the attempt to capture, document and clarify what cannot be excluded. The price you pay is that knowledge is no longer subversive, revealing, creative or even exciting." Ambiguity and critical thinking are crucial in the complex situations knowledge-intensive firms face nowadays (Alvesson, 2004). In addition to this focus on ambiguity when describing knowledge and learning in organizations, Alvesson (2004) also claims the label of knowledge management is sometimes overstretched and that it should be used with a greater sense of its drawbacks.

The same applies to the concepts of 'organizational learning' and the 'learning organization', critics also have suggested that the learning organization can be construed as an ideology which is far from reality in organizations as we know them today (e.g. Driver, 2002). Therefore, concepts like knowledge management and learning organizations are frequently seen as 'management trends' for which the effectiveness is difficult to demonstrate.

What is argued here is that one way of bridging this ambiguity and vagueness of knowledge and associated learning processes and the legitimate desire to intentionally regulate organizational matters is to insert a focus on talent management to establish a relation between knowledge management and performance. Talent and knowledge are closely related subjects (e.g. Arab \& Plucker, 2002). What makes talent management an attractive candidate for managing in knowledge-intensive situations relates to the triplet identified above of talent as a specific class of individuals ('A-performers'; these would become knowledge workers or knowledge subjects when approached from a knowledge perspective), a specific content (talent as high-level skills involves a key element of potential, and is meaningless without some domain that the talent applies to) and organizational positions (key positions refer to the organizational perspective, and thus may be used to step beyond the individual focus on people with their personal knowledge). Talent management can thus be used to avoid a limited functionalist approach to knowledge. By focusing on the talents of the workforce and by specifying these talents in knowledge related terminology (e.g. the content side to talent specified in relation to specific knowledge domains, the dynamic aspects of talents explored with respect to such processes as knowledge sharing and knowledge creation), knowledge enters the management domain in a way that avoids the risks of conceptual erosion of the knowledge concept. Knowledge functions as a gauge to select and specify talents considered crucial for meaningful persistence of the organization; it does not become the direct object of management. Also the concepts of talent management can function as a suited selection and specification vehicle within the broader HRM domain. Obviously, the social-practice sides to knowledge and learning processes call for a management focus on individuals and groups of individuals in connection to their organizational tasks and roles. Yet simply thinking of knowledge management as incomplete without human resource management would provide a not 
well-informed guide into the HRM field. Talent management is proposed here as a highly suited candidate for providing the missing link between the people side to management and knowledge-related challenges and problems within organizations.

Knowledge and learning are of fundamental importance in understanding organizations as adaptive systems. Regarding the strategic domain (viz. the discussion couched in terms of knowledge as a strategic resource or strategic capability) the use of talent management offers an attractive option to establish a positive relation between knowledge and learning on the one hand and the performance of organizations on the other. A reformulation and elaboration of knowledge-related talent management in strategic knowledge management terminology involves honouring the distinctive position that specific knowledge and learning capabilities may entail in a way that enables us to avoid a functionalist, objectivist perspective on knowledge without losing sight of the potential strategic boons of a knowledgeable workforce. Thus, a combined talent-knowledge focus on strategic positioning involves a potentially rich elaboration of strategic human resource management.

At the infrastructural level, talent management with a focus on the knowledge-related talents of employees also provides a powerful perspective on potentials and limitations of management in knowledge-intensive environments. Alvesson (2004) defines 'knowledgeintensive firms' as follows: 'organizations that offer to the market the use of fairly sophisticated knowledge or knowledge-based products. The core activities in these companies are based on the intellectual skills of a very large proportion of the labour force deployed in development, and often also in the sale of products and in service work' (Alvesson, 2004, p. 17). In these kinds of organizations, there is a strong focus on knowledge and on attracting and retaining knowledge workers who possess this knowledge. Therefore, within knowledge-intensive organizations, talent management can be significant in recruiting, developing and retaining talent. Within knowledge-intensive organizations, talented employees and their knowledge are considered important in producing those goods and services that yield and maintain competitive advantage. Connecting talent management to knowledge processes allows envisioning knowledge-related objectives as manageable entities. As examples of these knowledge processes and the way these would perceived via their relation to talent management, consider the processes of knowledge retention, knowledge sharing and knowledge creation. The first of these, knowledge retention, translates into identifying the key domains of knowledge that should not get lost into specific talents attached to these domains without modelling these domains (cf. the risks involved in knowledge modelling as identified by Ten Bos), and opens the door to specifying which A-performers, which talents and which key positions are pivotal in maintaining appropriate levels of organizational knowledge. Knowledge sharing as a talentrelated theme allows focusing on the tacit and explicit sides to knowledge without unduly treating these as separate categories. Perceiving of knowledge creation as a talent-related process allows focusing management attention not so much on the current knowledge per se, but on the potential current insight and associated reflection have for future insights that develop because of current knowledge yet deviate from it. The ambiguity and intransparancy of exactly this knowledge creation process thus remains centre stage in management efforts aimed at enhancing the creativity of the organization. Also broader conditions for these knowledge processes, such as the culture of the organization or shared worldviews among groups of personnel, may earn their appropriate place on the management agenda. The infrastructure of organizations needs to be regulated in a way that talent management can be established. When organizations launch talent management 
activities, a proper learning and working climate needs to be at hand (Christaensen et al., 2009). Therefore, without an existing learning climate, talent management activities cannot be launched in knowledge-intensive organizations.

\section{On how to manage talent as knowledge management}

To further elaborate on how a perspective on knowledge-related talent management provides an insight into possible management programmes and tools, attention needs to be paid to how objectives of talent management are to be specified. This concerns a necessary preparation for answering the third question posed in the introduction regarding the management practices of what can be labelled as 'knowledge-intensive talent management'. According to Van Beers (2005), the objectives of talent management are the optimal obtaining, mobilizing, developing and retaining of the talents which are needed for organizations to distinguish themselves on the market and in their provision of services'. This definition identifies two classes of objectives. Firstly, external objectives are included that concern distinguishing the organization from competitors or establishing its external identity (talents as vehicles for strategic positioning). These objectives link to the strong relation that exists between talent management and the strategic organizational objectives of the organization (Mensink, 1991; Van der Sluis, 2009). Thus the objectives of talent management can be described in terms of achieving competitive advantages and increased organizational performance. As signalled above, what talents are from a knowledge perspective is exactly those organizational knowing and learning capabilities that can be used to gain a competitive edge. To identify what strategic talents are, the knowledge management literature offers suited support in the processes of defining a knowledge strategy (e.g. the approach developed by Zack, 1999) that could be used in connection with a focus on talent to around knowledge domains, A-performers on these domains and key positions associated with the processing of these knowledge domains.

Next to these strategic objectives in Van Beers' definition, it also refers to the 'optimal obtaining, mobilizing, developing and retaining of the talents'. These objectives refer to organization-internal prerequisites for effective external positioning via talents. We will label this second class of objectives as infrastructural objectives: the objective of the organizational infrastructure will be to make sure that talents are and remain indoor that are indispensible for meeting the strategic objectives. A further specification of these infrastructural objectives is provided by Van der Sluis (2009) who states that talent management is about the finding, binding, captivating and flourishing of people in organizations with the goal of optimizing the labour productivity of their workforce'. Van der Sluis (2009) distinguishes the following three steps:

- Appoint and attract talent;

- Deploy and guide talent;

- Develop and bind talent.

When combining goals of talent management as presented by Van der Sluis (2009) and Van Beers (2005) the following list of infrastructural goals of talent management emerges:

- Finding: recruitment and selection.

- Binding: contracts, engagements/arrangements and inspiring confidence

- Captivating: providing perspective, professionalism and collegiality.

- Flourishing: performance, learning, innovation and excel, focus on talent development.

- Development: stimulate learning and development (career development). 
- Retain talent: by providing enough challenge in the work of professionals.

In addition to these objectives, Horowitz (2003: in Redman and Wilkinson, 2006), list the following objectives of talent management which are effective in motivating ('captivating'), developing and retaining talented knowledge workers:

- Having fundamentally interesting work: the work needs to be intrinsically, and continuously satisfying and stimulating;

- High levels of autonomy: workers need to be free to choose their own work activities and projects;

- Significant opportunities for self-development: there is a high need for continuous development under knowledge workers, which is a distinctive characteristic of this group of workers (Horowitz, 2003: in Redman \& Wilkinson, 2006, pp. 415-416).

Again, a clear connection can be observed when linking the concepts of knowledge and learning in organizations to the objectives of talent management. When pursuing the objectives of finding, binding, captivating, flourishing, developing and retaining talented employees (Van der Sluis, 2009; Van Beers, 2005) and by providing fundamentally interesting work, high levels of autonomy and significant opportunities for selfdevelopment (Horowitz, 2003 in Redman \& Wilkinson, 2006), talent management will be most effective. By using talent management as a means to fill in the performance side to knowledge management, a positive relationship between knowledge management and performance in organizations can be established. Pursuing the objectives of talent management as presented in this paragraph therefore can be used to strive for a higher knowledge-related performance of organizations.

The means for achieving these classes of talent management objectives provided in the literature and practice of talent management (e.g. Bhatnagar, 2007; Cseres \& Kelly, 2006; Farley, 2005; Frank et al., 2004; Romans et al., 2006; Romans \& Lardner, 2005), specifically concern a series of human resource practices. Talent management can be employed by making use of several practices; by implementing these practices it is assumed that the strategic objectives of talent management will be reached. Authors argue that organizations need to come up with 'bundles of HR practices' which are effective for motivating, developing and retaining talented knowledge workers (Redman and Wilkinson, 2006). Talent management practices are referred to in 'bundles', given the recognition that these processes need to be well integrated. Without a cohesive system of talent management practices, the required high performance will not be achieved (Heinen and O'Neill, 2004). The objectives of talent management as distinguished by Van der Sluis (2009) and Van Beers (2005) will again be used here to discuss the most suitable human resource practices. The bundles of human resource practices consist of:

- Recruitment and selection: find the talented employees organizations search for by means of applying accurate recruitment and selection practices. With recruitment and selection practices there has to be a proper 'fit' between new talent and the organization's current strategy and culture (Van der Sluis, 2009). Recruitment practices are vital in getting the right talent at the right place (Blass, 2009). When attracting talent, knowledge-intensive companies have to depict themselves as organizations having a clear focus on the personal development of these talented workers in a diverse environment.

- Contracts, arrangements and pay: to attach your talented employees to an organization, the organization has to provide knowledge workers with attractive levels of pay and reward packages (Horowitz, 2003: in Redman \& Wilkinson, 2006, p. 416). Talentoriented companies should provide talented employees with performance-based 
compensation packages, quality of life considerations and career development in an environment that promotes diversity and communicate these conditions of employment to the people they want to attract (Blass, 2009, p. 13).

- Providing perspective, professionalism and collegiality: in addition to the contractual arrangements, a confidential environment is important in binding talented employees to the organization (Van der Sluis, 2009). To captivate as well as motivate talent, the organization has to provide perspective in the form of opportunities to develop and by offering enough learning opportunities (Van der Sluis, 2009) which is in line with the next HR practice of talent development.

- Talent development: focus on innovation, performance and learning in order to develop the talents of employees. Talent development supports employees through their life cycle with the organization (Schiemann, 2009, p. 45). With talent development an existing learning climate has to be at hand (Christiaensen et al., 2009) to enable knowledge workers to constantly adapt their knowledge to new situations. Besides, every talented employee needs performance feedback on previous stated objectives of personal growth/development (Schiemann, 2009).

- Career development: to retain talented knowledge workers, enough career prospects have to be provided. A common problem in many knowledge-intensive organizations is for talented employees to leave their jobs because they are not being allowed to do as much as they would like to do for their organizations (Blass, 2009). Talented workers should be stimulated to constantly develop their talents in working towards higher job levels. Retaining talented workers also flows from constantly providing enough challenge in the work of professionals and again from contractual arrangements such as specific levels of pay (Van der Sluis, 2009; Van Beers, 2005).

In the description of these different human resource practices of talent management, a clear connection between these practices and knowledge and learning in organization becomes visible. In recruiting and selecting talented employees a strong focus can be put on the knowledge of these talented employees. Besides, in certain knowledge-intensive firms (Alvesson, 2004), potential employees will only be selected from a certain level of education (for instance an academic degree). The knowledge these talented employees possess is assumed to be strategic and decisive in achieving competitive advantage. The 'War for Talent' (Fishman, 1998) consists of attracting highly skilled, knowledgeable workers. Learning in organizations is also significant in, for example, the practices of 'career development', 'talent development' and providing 'perspective'. Without a learning climate, talented knowledge workers will not get the opportunity to develop themselves (Christiaensen et al., 2009); this learning climate is therefore very important when considering these practices. A learning climate means having enough possibilities to constantly adapt knowledge workers' knowledge to new situations. Because of this learning climate, the knowledge worker is constantly learning and will be provided enough challenges to remain within the organization.

\section{Conclusion}

By means of a literature review of talent management, the main objective of this paper was to explore the connections between knowledge and learning in organizations and talent management. More specifically, talent management has been used as a potentially interesting specification vehicle for establishing the relationship between knowledge 
management and organizational performance. In this paper four different streams of talent management have been identified, and sorted into the two main streams of approaching talent as 'A-performers' and key positions along with two auxiliary streams addressing associated HR practices and talent pool management activities. It has been argued that because of the vagueness, broadness and ambiguity of knowledge, a direct link between knowledge and organizational performance remains evasive. Given the assertion that knowledge is first and foremost organizationally relevant if and when it forms the basis for generating new knowledge - and thus when present knowledge is not enough for securing a viable and meaningful strategic position for organizations - using knowledge as the guiding light when drafting strategic courses would appear futile. What would such strategic choice look like when based on vagueness, ambiguity, and dispute centred on what organizations do not know (which is strategically highly relevant) as opposed to the certainties of what they do know (which in themselves are strategically hardly interesting)? Talent management, when aimed at combining insights on 'A-performers' with insights on key positions, has been proposed as a means to fill in the performance side of knowledge management in organizations as talent concerns exactly the type of conditions not just to apply current knowledge but also to generate new insights and foster deep learning.

What the talent management literature shows is that setting the goals of finding, binding, captivating, flourishing, developing and retaining talented employees (Van der Sluis, 2009; Van Beers, 2005) and providing fundamentally interesting work, high levels of autonomy and significant opportunities for self-development (Horowitz, 2003, in Redman and Wilkinson, 2006), will result in making talent management most effective. Furthermore, the human resource practices 'recruitment and selection', 'contracts, arrangements and pay', 'providing perspective, professionalism and collegiality', talent development' and 'career development' should be integrated and aligned with the firm's business strategy in order to pursue these stated goals. In this paper it has been argued that by focusing on talented employees and by using their capabilities in order to strive for performance, the 'black box' between HRM practices and performance can be opened up.

The importance of HRM practices for effective knowledge management has been acknowledged by many authors in the knowledge management field (Hislop, 2009, p. 239). By developing the commitment and loyalty of workers to share, codify and create knowledge, HRM policies can play a crucial role in supporting organizational knowledge management (Hislop, 2009). In this debate talent management has not yet been recognized as a means to specify the HRM practices of knowledge management. When considering knowledge and learning in organizations it appears natural to focus on talented employees because they possess the specific creative abilities needed to survive in a knowledgeintensive environment. Several authors emphasize the importance of talent management when striving for organizational performance (Fishman, 1998). According to Heinen and O'Neill (2004), talent management practices can create the most enduring competitive advantages. Sustained competitive advantage comes from talent management practices, how the organization attracts, develops, motivates, manages and rewards its talent (Heinen and O'Neill, 2004, p. 67). Talent management can become effective only when talent management processes are integrated into a firm's business strategy. As a consequence, to be successful, the talent strategy must be aligned with an organization's business strategy and human capital context (Heinen and O'Neill, 2004). Talent management practices are supposed to create the most enduring competitive advantages (Heinen and O'Neill, 2004). But because of a lack of research-based evidence, the productive link between talent 
management and performance has not been empirically confirmed (Lewis \& Heckman, 2006). Establishing a concrete link between talent management programs and performance metrics proves to remain difficult (Farley, 2005). 'The topic talent management has been enthusiastically pursued in the trade and popular press without being systematically linked to peer-reviewed, research-based findings' (Lewis \& Heckman, 2006, p. 142).

Despite the lack of research-based evidence regarding the relationship between talent management and performance of organizations, this paper has argued that managing around talent in light of knowledge-related challenges and problems may serve as a useful beacon in attempts to increase performance. A condition that has to be met, however, is that talent management practices are well integrated and aligned with the firm's business strategy. More research is needed to determine whether, how and when implementing talent management activities will actually lead to business success when knowledge and learning are defined as key beacons for setting a strategic course and providing the organizational conditions when needed to adjust the course while following to it. The effectiveness of talent management as a potentially powerful specification of a knowledge management approach therefore needs to be further examined by future empirical research. To conclude this paper we offer some discussion elements regarding possible future studies and $\mathrm{KM}$ practices in the combined domain of knowledge management and talent management. Talent management has been interpreted here as a means to increase organizational performance. It should be seen as a potential HR system (bundle of practices) for managing knowledge in knowledge-intensive settings. Implementing the bundles of human resource practices in talent management programmes (e.g. Blass, 2009; Schiemann, 2009; Van Beers, 2005; Van der Sluis, 2009), as has been distinguished in paragraph 4, will help knowledge-intensive organizations in establishing a concrete link between managing knowledge and learning on the one hand and striving for organizational performance on the other. By implementing the proper recruitment and selection practices, personnel with a specific knowledge level will enter the organization. Their knowledge will be managed by means of providing them with adequate arrangements and development possibilities. When these talented employees develop their skills and knowledge within the organization, the organization is assumed to benefit as well. Furthermore, by means of these talent management-geared HR practices, knowledge workers (also defined as 'talent' or 'A performers'), are assumed to constantly learn within this organizational environment. Talent management has therefore been interpreted as an attempt to increase the organizational performance. Future studies regarding the effectiveness of talent management are required to broaden our understandings regarding the connections between knowledge management and increased performance rates of organizations. Recommendations for subjects to be addressed in future studies elaborating the talent management-knowledge management connection include:

- How to enable talented workers to share their knowledge;

- How to create a learning climate in which talented workers will gain enough possibilities for developing themselves (personally as well as technically);

\section{References}

Adams, J. (2006). Managing People in Organizations: contemporary theory and practice, Palgrave, Houndmills

Alvesson, M. (1993). Organizations as Rhetoric - Knowledge-Intensive Firms and the Struggle with Ambiguity. Journal of Management Studies, Vol. 30, No. 6, pp. 997-1015 
Alvesson, M. (2001). Knowledge work: Ambiguity, image and identity. Human Relations, Vol. 54, No. 7, pp. 863-886

Alvesson, M. (2004). Knowledge work and knowledge-intensive firms, Oxford University Press, Oxford

Alvesson, M., \& Karreman, D. (2001). Odd couple: Making sense of the curious concept of knowledge management. Journal of Management Studies, Vol. 38, No. 7, pp. 995-1018

Ashton, C. \& Morton, L. (2005). Managing Talent for Competitive Advantage, Strategic HR Review, Vol. 4, No. 5, pp. 28-31

Barab, S.A., \& Plucker, J.A. (2002). Smart People or Smart Contexts? Cognition, ability and talent development in an age of situated approaches to knowing and learning. Educational Psychologist, Vol. 37, No. 3, pp. 165-182

Becker, M. C. (2001). Managing dispersed knowledge: Organizational problems, managerial strategies, and their effectiveness. Journal of Management Studies, Vol. 38, No. 7, pp. 1037-1051

Bhatnagar, J. (2007). Talent management strategy of employee engagement in Indian ITES employees: key to retention. Employee Relations, Vol. 29, No. 6, pp. 640-663

Blass, E. (2009). Talent management: cases and commentary, Palgrave Macmillan (Palgrave connect online services), New York

Boselie, P. , Dietz, G. \& Boon, C. (2005). Commonalities and contradictions in HRM and performance research, Human Resource Management Journal, Vol. 15, pp. 67-94

Boxall, P. \& Purcell, J. (2008). Strategy and Human Resource Management (second edition), Palgrave Macmillan, Basingstoke

Brown, J.S. \& Duguid, P. (1998). Organizing knowledge. California Management Review, Vol. 40, No. 3, pp. $90-111$

Cappelli, P. (2008). Talent management for the $21^{\text {st }}$ century, Harvard Business Review, March 2008, pp. 74-81

Chiva, R. \& Alegre, J. (2005). Organizational learning and organizational knowledge Towards the integration of two approaches. Management Learning, Vol. 36, No. 1, pp. $49-68$

Christiaensen, R., Dochy, F., Kinschots, C., Kyndt, E., Marcelis, V., Philips, K., Van Cauwenberghe, H., Van den Bogaert, T. \& Vervaeke, A. (2009). Talent and Talent development: a literature review [Talent en Talentontwikkeling: een literatuurstudie], University of Leuven, Leuven

Collings, D.G. \& Mellahi, K. (2009). Strategic Talent Management: A review and research agenda, Human Resource Management Review, Vol. 19, No. 4, pp. 304-313

Cook, S.D.N. \& Brown, J.S. (1999). Bridging epistemologies: The generative dance between organizational knowledge and organizational knowing. Organization Science, Vol. 10, No. 4, pp. 381-400

Cseres, P. , \& Kelly, N. (2006). Restructuring talent sourcing at DuPont. Strategic Human Resource Review, Vol. 6, No. 1, pp. 28-31

Driver, M. (2002). The learning organization: Foucauldian gloom or Utopian sunshine? Human Relations. Vol. 55, No. 1, pp. 33-53

Farley, C. (2005). HR's role in talent management and driving business results. Employment Relations Today, Vol. 32, No. 1, pp. 55-61

Fishman, C. (1998). The war for talent. http://www.accordsyst.com/papers/talent_war.doc 
Frank F. D., Finnegan, R. P. \& Taylor C. R. (2004). The race for talent: Retaining and engaging workers in de 21st century. Human Resource Planning, Vol. 27, No 3, pp. $12-25$

Frank, F.D. \& Taylor, R.C. (2008). Talent management: Trends that will shape the future, Human Resource planning, Vol. 27, No. 1, pp. 33-42

Haesli, A. \& Boxall, P. (2005). When knowledge management meets HR strategy: an exploration of personalization-retention and codification-recruitment configurations. International Journal of Human Resource Management, Vol. 16, No. 11, pp. 1955-1975

Harrison, R. \& Kessels, J. (2004). Human Resource Development in a Knowledge Economy - An organisational view, Palgrave Macmillan, New York

Heinen, J.S. \& O'Neill, C. (2009). Managing Talent to Maximize Performance, Employment Relations Today, Vol. 31, No. 2, pp. 67-82

Hislop, D. (2009). Knowledge Management in Organizations (second edition), Oxford University Press, Oxford

Kaulingfreks, R. (2002). Reflections on Knowledge, Management and Thinking [Bedenkingen over Kennis, Management en Denken], In: Kennis en Management, P. v. Baalen, M. Weggeman \& A. Witteveen (Eds.), pp. 208-232, Scriptum, Schiedam

Kessels, J.W.M. (2004). The knowledge revolution and the knowledge economy: the challenge for HRD, In: New Frontiers in HRD, Woodall, J., Lee, M. \& Stewart, J. (Eds.), pp. 165-179. Routledge, London

Lewis, R.E. \& Heckman, R.J. (2006). Talent management: A critical review, Human Resource Management Review, Vol. 16, pp. 139-154

Mensink, J.C.M. (1991). Dynamics in human resource management: using talents as policy [Dynamiek in human resource management: talenten benutten als beleid], Lemma, Utrecht

Nonaka, I. (1994). A dynamic theory of organizational knowledge creation, Organization Science, Vol. 5, No. 1, pp. 14-37.

Redman, T. \& Wilkinson, A. (2006). Contemporary Human Resource Management - Text and Cases. Second edition, Pearson Education Limited, Harlow

Romans, J., \& Lardner, L. (2005). Integrated talent management at BD Japan. Strategic Human Resource Review, Vol. 4. No. 5, pp. 16-19

Romans, J., Frost, A., \& Ford, S. (2006). Developing high - potential talent at Hughes Supply, Strategic Human Resource Review, Vol. 5, No. 3, pp. 32-35

Scarbrough, H. (2003). Knowledge management, HRM and the innovation process. International Journal of Manpower, Vol. 24, No. 5, pp. 501-516

Schiemann, W.A. (2009). Reinventing Talent Management, How to Maximize Performance in the New Marketplace, Wiley, Hoboken (New Jersey)

Schultze, U. \& Stabell, C. (2004). Knowing what you don't know? Discourses and contradictions in knowledge management research. Journal of Management Studies, Vol. 41, No. 4. pp. 549-573

Sewell, G. (2005). Nice work? Rethinking managerial control in an era of knowledge work. Organization, Vol. 12, No. 5, pp. 685-704

Smart, B.D. (1999). Top grading: How leading companies win by hiring, coaching, and keeping the best people, Prentice Hall Press, Paramus, NJ 
Storey, J. \& Quintas, P. (2002). Knowledge Management and HRM. In J. Storey (Ed.), Human Resource Management: A Critical Text (2nd Ed.), pp. 339-363, Thomson Learning, London

Ten Bos, R. (2002). Paradigms and the organization of knowledge [Paradigma's en de organisatie van kennis]. In: Kennis en management, P. v. Baalen, M. Weggeman \& A. Witteveen (Eds.), pp. 33-52, Scriptum, Schiedam

Tsoukas, H. (1996). The firm as a distributed knowledge system: a constructionist approach. Strategic Management Journal, Vol. 17, Special Issue Winter 1996, pp. 11-26.

Tsoukas, H. (2003). Do we really understand tacit knowledge? In: The Blackwell Handbook of Organizational Learning and Knowledge Management, M. Easterby-Smith \& M.A. Lyles (Eds), pp. 410-427, Blackwell, Malden

Tsoukas, H. (2005). Complex knowledge: studies in organizational epistemology, Oxford University Press, Oxford

Van Aken, T. (1991). Talent management: deploying talent of vital importance to organizational success [Talent management: inzet van talent van levensbelang voor succes van organisaties]. Personeelbeleid, Vol. 27, No. 9, pp. 458-478

Van Beers, W. (2005). Performance management, competency management and talent management: three sides of a coin? [Performance management, competentie management en talentmanagement: drie kanten van één medaille?]. Opleiding $\mathcal{E}$ Ontwikkeling, Vol. 18, No. 5, pp. 26-28

Van der Sluis, L. (2009). Competing for talent, Van Gorcum, Assen

Zack, M.H. (1999). Developing a knowledge strategy. California Management Review, Vol. 41, No. 3, pp. $125-145$ 


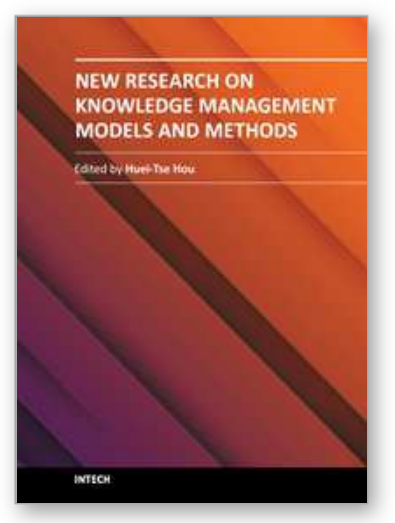

\author{
New Research on Knowledge Management Models and Methods \\ Edited by Prof. Huei Tse Hou
}

ISBN 978-953-51-0190-1

Hard cover, 426 pages

Publisher InTech

Published online 23, March, 2012

Published in print edition March, 2012

Due to the development of mobile and Web 2.0 technology, knowledge transfer, storage and retrieval have become much more rapid. In recent years, there have been more and more new and interesting findings in the research field of knowledge management. This book aims to introduce readers to the recent research topics, it is titled "New Research on Knowledge Management Models and Methods" and includes 19 chapters. Its focus is on the exploration of methods and models, covering the innovations of all knowledge management models and methods as well as deeper discussion. It is expected that this book provides relevant information about new research trends in comprehensive and novel knowledge management studies, and that it serves as an important resource for researchers, teachers and students, and for the development of practices in the knowledge management field.

\title{
How to reference
}

In order to correctly reference this scholarly work, feel free to copy and paste the following:

Melissa Schroevers and Paul Hendriks (2012). Talent Management in Knowledge-Intensive Organizations, New Research on Knowledge Management Models and Methods, Prof. Huei Tse Hou (Ed.), ISBN: 978-95351-0190-1, InTech, Available from: http://www.intechopen.com/books/new-research-on-knowledgemanagement-models-and-methods/talent-management-in-knowledge-intensive-organizations

\section{INTECH}

open science | open minds

\author{
InTech Europe \\ University Campus STeP Ri \\ Slavka Krautzeka 83/A \\ 51000 Rijeka, Croatia \\ Phone: +385 (51) 770447 \\ Fax: +385 (51) 686166 \\ www.intechopen.com
}

\author{
InTech China \\ Unit 405, Office Block, Hotel Equatorial Shanghai \\ No.65, Yan An Road (West), Shanghai, 200040, China \\ 中国上海市延安西路65号上海国际贵都大饭店办公楼 405 单元 \\ Phone: +86-21-62489820 \\ Fax: +86-21-62489821
}


(C) 2012 The Author(s). Licensee IntechOpen. This is an open access article distributed under the terms of the Creative Commons Attribution 3.0 License, which permits unrestricted use, distribution, and reproduction in any medium, provided the original work is properly cited. 